\title{
THE ETIOLOGY, TREATMENT AND OUTCOME OF DIABETIC KETOACIDOSIS AND HYPEROSMOLAR COMA
}

\section{ETIOLOGIJA, TERAPIJA I ISHOD DIJABETESNE KETOACIDOZE I HIPEROSMOLARNE KOME}

\author{
Dragana Melentijević ${ }^{1}$, Teodora Beljić Živković ${ }^{2,3}$
}

\section{Summary}

Diabetic ketoacidosis (DKA) and nonketotic hyperosmolar hyperglycemic state (NHOK) are acute complications of diabetes mellitus (DM). The aim was to investigate precipitating factors, therapy and the result of the treatment of DKA and NHOK.

The study included all the people who were admitted to the Clinical Department of Endocrinology, Diabetes and metabolism disease KBC "Zvezdara" in the state of DKA and NHOK between 2007 and 2010.

During this period we treated 56 people, aged $51.8 \pm 18.8$ years. DKA was diagnosed in 54 patients, whereas NHOK was diagnosed in two patients. Type 1 DM was present in 26 (46.42\%) patients and type 2 in 30 (53.57\%) patients.

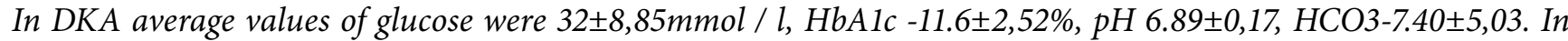
patients with NHOK average glucose was $60.35 \pm 15,14 \mathrm{mmol} / \mathrm{l}$,

HbA1c-11.2 $\pm 1,7 \%, p H 7.43 \pm 0,1, H C O 3-19,8 \pm 5,23$. There was a significant difference in the glucose level $(t(54)$ $=6.03, p<0.01)$ as well as in bicarbonate level $(t(54)=3.72, p=0.01)$ between $D K A$ and NHOK. The most common precipitating factors were: infection in $26(46.42 \%)$ cases, inadequate therapy in $24(42.85 \%)$ cases, myocardial infarction and cerebral stroke in 2 (3.57\%) cases. All the patients with NHOK and 16 with DKA had previously been on oral antihyperglycemic drugs, while 29 patients with DKA had previously been on insulin therapy. Upon admission, the previous therapy was not in relation with the level of glucose and $p H$. Bicarbonate level was significantly higher in the group treated with oral therapy $(t(43)=2.16, p<0.05)$. The therapy was considered because of rehydration, fractionally giving boluses HM insulin, potassium compensation and treatment precipitating factors. Rehydration was achieved with an average of 5.6 $\pm 1,65$ liters on the first day,4.08 $\pm 0,87$ on the second day, and $3 \pm 0,01$ liters on the third day of infusion solutions. The total daily dosage of insulin bolus HM on the first day was 81.04 $27,97 i . j, 59.64 \pm 17,60 i . j$. on the second day and 58.06 $\pm 19,70$ i.j. on the third day. Maximum daily supplementation of potassium in the form of 7.4\% KCL solution was $61 \pm 18,70 \mathrm{mmol} / \mathrm{l}$. Upon the end of the treatment, the total of $26(46.42 \%)$ was discharged on basal - bolus human insulin therapy, 18 (32.14\%) on the treatment of basal - bolus analogues, 11 (19.64\%) on therapy insulin premix and metformin, while two (3.57\%) were discharged on oral antihyperglycemic medications. The treatment outcome was successful in 50 people (89.3\%), while death occurred in 6 (10.7\%) cases. The most common complication was hypokalemia, present in $29(51.78 \%)$ patients. Other complications were acute renal failure (3 people), acute respiratory distress syndrome (2 people), pulmonary edema (2 people) and gastrointestinal bleeding (1 person).

Despite education and available medications for diabetes, acute complications of diabetes can still occur and are sometimes accompanied by dangerous complications.

Key words: diabetic ketoacidosis, nonketotic hyperosmolar hyperglycemic state

\section{Sažetak}

Dijabetesna ketoacidoza (DKA) i hiperosmolarna neketonska hiperglikemijska koma (NHOK) su akutne komplikacije dijabetesa melitusa (DM).

Cilj rada bio je ispitivanje precipitirajućih faktora, terapije i ishoda lečenja osoba sa DKA i NHOK.

Ispitivanje je obuhvatilo sve osobe koje su primljene na Kliničko odeljenje za endokrinologiju, dijabetes $i$ bolesti metabilizma KBC „Zvezdara“ u stanju DKA i NHOK u periodu 2007 - 2010. godine.

U naznačenom priodu lečeno je 56 osoba, starosti 51,8 18,8 godina. DKA je dijagnostikovana kod 54, a NHOK kod 2 pacijenta. DM tip 1 bio je prisutan u 26 (46,42\%), a tip 2 u 30 (53,57\%) pacijenata.

UDKA prosečne vrednosti glikemije bile su $32 \pm 8,85 \mathrm{mmol} / \mathrm{l}, \mathrm{HbA1c} 11,6 \pm 2,52 \%, p H 6.89 \pm 0,17, \mathrm{HCO}-7,40 \pm 5,03$. Kod 2 pacijenata sa NHOK prosečna glikemija $60,35 \pm 15,14 \mathrm{mmol} / \mathrm{l}, \mathrm{HbAlc} 11,2 \pm 1,7 \%, p H 7,43 \pm 0,1, \mathrm{HCO}-19,8 \pm 5,23$. Između DKA i NHOK bila je značajana razlika u visini glikemije $(t(54)=6,03, p<0,01)$ i nivou bikarbonata $(t(54)=3,72, p=0,01)$. Najčešći precipitirajući faktori bili su: infekcija 26(46,42\%), neadekvatna terapija 24 (42,85\%), infarkt miokarda i cerebrovaskularni insult 2(3,57\%). Svi pacijenti sa NHOK i 16 sa DKA bilo je prethodno na oralnim antihiperglikemijskim lekovima, dok je 29 njih sa DKA bilo prethodno na insulinskoj terapiji. Predhodna terapija nije korelirala sa nivoom glikemije i pH na prijemu. Nivo bikarbonata je značajno bio veći u grupi lečenih oralnom terapijom $(t(43)=2,16, p<0,05)$. 
Lečenje je podrazumevalo rehidrataciju, frakcionirano davanje bolusnog HM insulina, nadoknadu kalijuma i lečenje

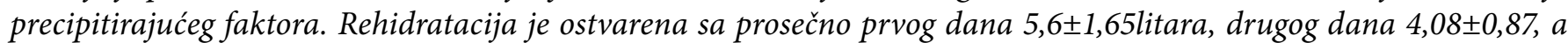

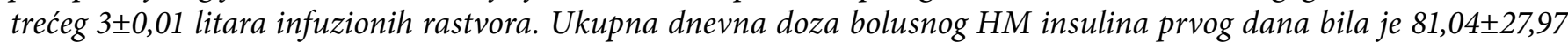



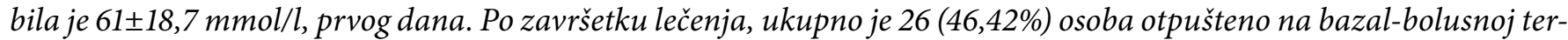
apiji humanim insulinom, 18 (32,14\%) na bazal-bolusnoj terapiji analozima, 11 (19,64\%) na terapiji premiks insulina $i$ metformina, dok je dvoje (3,57\%) otpušteno na oralnim antihiperglikemijskim lekovima. Ishod lečenja je bio upešan u 50 osoba (89,3\%), smrtni ishod nastupio je u 6 (10.7\%) osoba. Najčeš́ć komplikacija bila je hipokalijemija, prisutna u 29 (51,78\%) lečenih. Ostale komplikacije bile su: akutna bubrežna insuficijencija (3 osobe), akutni respiratorni distres sindrom (2 osobe), edem pluća (2 osobe) i gastrointestinalno krvavljenje (1 osoba).

Zaključimo, i pored edukacije i potpune dostupnosti lekova za šećernu bolest, akutne komplikacije dijabetesa se ipak dešavaju i praćene su ponekad opasnim komplikacijama.

Ključne reči: dijabetesna ketoacidoza, hiperosmolarna koma

\section{UvoD}

Dijabetesna ketoacidoza (DKA) i hiperosmolarna neketonska hiperglikemijska koma (NHOK) su akutne, potencijalno veoma opasne komplikacije dijabetes melitusa (DM). DKA se češće javlja kod dijabetes melitus tipa 1(1), a NHOK kod DM tip 2 tipično kod starijih pacijenata sa komorbiditetima, sa umerenim diabetesom, najčešće lečenim oralnim antihiperglikemijskim agensima koji neredovno uzimaju terapiju (2). Najčešći precipitirajući faktor za razvoj DKA je infekcija (najčešće urinarna, zatim respiratorna i na trećem mestu kožna infekcija) (3). Drugi uzroci su diskontinuirana ili neadekvatna insulinska terapija, kardiovaskularni događaji, moždani udar, hirurške intervencije, akutna alkoholisanost, akutni pankreatitis, upotreba nekih lekova. Lekovi kao što su kortikosteroidi, tiazidni diuretici, simpatikomimetici i pentamidini mogu precipitirati razvoj ketoacidoze (4).

Najčešći precipitirajući faktor za razvoj NHOK je infekcija, iznurenost, komorbiditet (CVI, demencija, infarkt miokarda, bubrežna slabost) ili socijalna situacija koja remeti unos vode. Kao precipitirajući faktor se navodi i upotreba pojedinih lekova (tiazidni diuretici, glikokortikoidi, fenitoin) (5).

U odnosu na težinu metaboličkog disbalansa i stepen poremećaja svesti, postoje tri oblika dijabetesne ketoacidoze. To su laka, umerena i teška ketoacidoza. (6). Njihove međusobne razlike prikazane su u Tabeli 1.

Osnovna terapijska mera u lečenju stanja DKA je rehidratacija. Daje se $0,9 \% \mathrm{NaCl}$ u količini od $10-20 \mathrm{ml} / \mathrm{kg} /$ TT/čas (7). Nadoknada kalijuma (K) je druga osnovna mera u terapiji DKA. Nivo $K$ se prati na $2-4$ časa i nadoknada ne bi trebalo da bude brža od $40 \mathrm{ml} \mathrm{7,4 \%} \mathrm{KCl}$ na 1 čas (u slučaju $K<3,5 \mathrm{mmol} / \mathrm{l}$ ) (8). Nadoknada insulina je na trećem mestu po prioritetu. Insulinska terapija kod DKA je 0.1i.j./kg/čas i.v. u $500 \mathrm{ml}$ rastvora. Insulin se daje u drugi litar rastvora, pošto je započeta nadoknada kalijuma (38). Ukoliko je $\mathrm{pH}<7.2$ može se dodati 100 $\mathrm{ml} 4,2 \%$ bikarbonata tokom $30 \mathrm{~min}$. Ukoluko je $\mathrm{pH}<7,0$ nadoknada bikarbonata se ostvaruje sa $100 \mathrm{ml} \mathrm{8,4 \%} \mathrm{ras-}$ tvorom natrijum bikarbonata putem najšire igle (9).
Najčešće komplikacije DKA su hipokalijemija i hipoglikemija, cerebrovaskularni insult, akutni respiratorni distres sindrom i edem pluća, akutna bubrežna insuficijencija (10), hipofosfatemija, akutna dilatacija želuca, tromboembolije. Smrtnost u DKA je 0,5-2\% (43).

Terapija NHOK se zasniva na brzoj rehidrataciji. U prvih dva sata daje se 2-3 litra fiziološkog rastvora (11). Nadoknada kalijuma je izuzetno važna. Ukoliko je $\mathrm{K}<$ $3,5 \mathrm{mmol} / \mathrm{l}$ ne daje se insulin. Nadiknada $\mathrm{K}$ vrši se rastvorom 7,4\% $\mathrm{KCl} 40 \mathrm{ml} \mathrm{u}$ prvi litar rastvora u toku prvog sata, potom $20 \mathrm{ml}$ na litar rastvora na sat vremena, sve do normalizacije. Kratkodelujući insulin (regularni HM insulin) se dodaje u količini od 0.1i.j./kg/h. (12).

Najčešće komlikacije koje prate stanje hiperosmolarne neketonske hiperglikemijske kome su rabdomioliza, DIK, tromboembolija (13), akutna renalna insuficijencija i edem pluća (14). Smrtnost u DKA je 0,5-2\% (15).

\section{Cilj RAda}

Primarni cilja ovog rada je ispitivanje precipitirajućih faktora, terapije i ishoda lečenja u osoba sa dijabetesnom ketoacidozom i hiperosmolarnom hiperglikemijskom neketonskom komom. Sekundarni cilj ispitivanja je poređenje uticaja predhodne terapije i glikoregulacije na ozbiljnost metaboličkog poremećaja, dalje lečenje i pojavu komplikacija.

\section{Metod}

Ovom studijom preseka, obuhvaćeni su pacijenti koji su u periodu 2007. do 2010. godine hospitalizovani na Kliničkom odeljenju za endokrinologiju, dijabetes i bolesti metabilizma KBC Zvezdara. Laboratorijski kriterijumi za dijagnozu dijabetesne ketoacidoze na hitnom internističkom prijemu bili su glikemija $>16 \mathrm{mmol} / 1, \mathrm{pH}<7,3$, $\mathrm{HCO} 3<15 \mathrm{mmol} / \mathrm{l}$, osmolalnost $>300 \mathrm{mOsmo} / \mathrm{l}$. Kriterijumi za dijagnozu hiperosmolarne neketonske hiper- 
Tabela 1. Oblici dijabetesne ketoacidoze;

Table 1. Forms of diabetic ketoacidosis

\begin{tabular}{|c|c|c|c|}
\hline & $\begin{array}{l}\text { Blaga } \\
\text { Mild }\end{array}$ & $\begin{array}{l}\text { Umerena } \\
\text { Moderate }\end{array}$ & $\begin{array}{l}\text { Teška } \\
\text { Serious }\end{array}$ \\
\hline $\begin{array}{l}\text { Glikemija mMol } \\
\text { Glycemia mMol }\end{array}$ & $>15$ & $>15$ & $>15$ \\
\hline $\begin{array}{l}\text { Arterijski pH } \\
\text { Arterial pH }\end{array}$ & $7.25-7.30$ & $7.00-7.24$ & $<7.00$ \\
\hline $\begin{array}{l}\text { Bikarbonati mEq/l } \\
\text { Bicarbonates mEq/1 }\end{array}$ & $15-18$ & $10-15$ & $<10$ \\
\hline $\begin{array}{l}\text { Ketoni/ urin } \\
\text { Ketones/urine }\end{array}$ & + & + & + \\
\hline $\begin{array}{l}\text { Ketoni/ serum } \\
\text { Ketones/serum }\end{array}$ & + & + & + \\
\hline $\begin{array}{l}\text { Plazma EOsm } \\
\text { Plasma EOsm }\end{array}$ & $\begin{array}{l}\text { Varijabilna } \\
\text { Variable }\end{array}$ & $\begin{array}{l}\text { Varijabilna } \\
\text { Variable }\end{array}$ & $\begin{array}{l}\text { Varijabilna } \\
\text { Variable }\end{array}$ \\
\hline $\begin{array}{l}\text { Anjonska praznina } \\
\text { Anion gap }\end{array}$ & $>10$ & $>12$ & $>12$ \\
\hline $\begin{array}{l}\text { Poremećaj svesti } \\
\text { Disturbance of consciousness }\end{array}$ & $\begin{array}{c}\text { Normalna svest } \\
\text { Normal consciousness }\end{array}$ & $\begin{array}{c}\text { Pomućena svest } \\
\text { Confused consciousness }\end{array}$ & $\begin{array}{l}\text { Koma } \\
\text { Coma }\end{array}$ \\
\hline
\end{tabular}

glikemijske kome na hitnom internističkom prijemu bili su glikemija $>40 \mathrm{mmol} / \mathrm{l}, \mathrm{pH}>7,3, \mathrm{HCO} 3>20 \mathrm{mmol} / \mathrm{l}$, osmolalnost $>335 \mathrm{mOsmo} / \mathrm{l}$. Podaci su dobijeni iz istorija bolesti bolesnika koji su u navedenom periodu lečeni. U toku hospitalizacije pacijentima je određivana osnovna biohemija, HbAlc, elekrolitni status, gasne analize i $\mathrm{pH}$ vrednost krvi, izračunata osmolarnost (osmolarnost $(\operatorname{mosm} / \mathrm{l})=2 \times(\mathrm{Na}+\mathrm{K})+$ glukoza + ureja $)$ i anjonska praznina $(\mathrm{Na}-(\mathrm{Cl}+\mathrm{HCO} 3))$ na osnovu dobijenih laboratorijskih vrednosti. Traženo je prisustvo precipitirajućih faktora. Na osnovu fizikalnog nalaza, hematoloških parametara i drugih dijagnostičkih procedura intenzivno je tragano za prisustvom infektivnog žarišta.

Uvidom u medicinsku dokumentaciju analizirani su parametri: pol, godine života i tip dijabetesa. Beleženo je prisustvo precipitirajućih faktora. To su najčešće bili: akutni koronarni sindrom, CVI, infekcija i tip infekcije, akutni pankreatitis, uzimanje alkohola i neredovno uzimanje terapije koje dosta često pacijente vodi u akutne komplikacije dijabetesa. Praćena je predhodna glikoregulacija kroz HbAic i prisustvo predhodnih akutnih i hroničnih komplikacija dijabetesa. Zabeležena je antidijabetesna i druga terapija pre hospitalizacije.

Zapisana je terapija sa liste intenzivne nege u prva tri dana hospitalizacije (dnevno određivanje količine tečnosti koja je primenjena $u$ rehidrataciji, broj jedinica insulina aplikovan na dnevnom nivou, maksimalna količina datog K u danu, davanje bikarbonata). Zabeležena je i terapija sa kojom je pacijent otpušten iz bolnice i preporuka za dalje lečenje.

Praćen je razvoj komplikacija i ishod lečenja. Zabeleženi su: mortalitet, prisustvo neuroloških komplikacija, hipokalijemije, hipoglikemije, akutni respiratorni distres sindrom, edem pluća, akutna bubrežna insuficijencija, tromboza, rabdomioliza i gastrointestinalno krvarenje.

Podaci su analizirani metodama deskriptivne i analitičke statistike. Deskriptivni statistički metodi korišćeni za opisivanje uzorka su aritmetička sredina i standardna devijacija. Za poređenje grupa korišćeni su parametarski (jednofaktorska ANOVA, t test) i neparametarski testovi (hi kvadrat test). Za statističku obradu podataka korišćen je računarski softverski program SPSS. Podaci su prikazani tabelarno i grafički.

\section{ReZULTATI}

U naznačenom priodu, od 2007-2010. godine lečeno je 56 osoba. DKA je dijagnostikovana kod 54, a NHOK kod 2 pacijenta. Od 56 hospitalizovane osobe 29 osoba je ženskog, 27 muškog pola, prosečne starosti $51,8 \pm 18,8$ godina (Tabela 2). Dijabetes mellitus tip 1 bio je prisutan u 26 $(46,42 \%)$, a tip 2 u $30(53,57 \%)$ pacijenata.

Tabelom 3 prikazana je distribucija hospitalizivanih $\mathrm{u}$ posmatranom periodu gde se primećuje opadajući trend 
Tabela 2. Distribucija lečenih po polu i uzrastu;

Table 2. Distribution treated by sex and age

$\begin{array}{lccc}\text { GODINE } & \text { M } & \check{Z} & \begin{array}{l}\text { ukupno u uzrasnoj grupi } \\ \text { total of the age group }\end{array} \\ \text { AGE } & \text { M } & \text { F } & 15(26.8 \%) \\ 18-39 & 8 & 7 & 21(37.5 \%) \\ 40-59 & 12 & 9 & 17(30.4 \%) \\ 60-79 & 7 & 10 & 3(5.3 \%) \\ 80-89 & 0 & 3 & 56(100 \%) \\ \text { Ukupno } & 27 & 29 & \\ \text { Total } & & & \end{array}$

Tabela 3. Distribucija hospitalizovanih u posmatranom periodu Table 3. Distribution of hospitalized patients in the reporting period

$\begin{array}{lccc}\begin{array}{l}\text { Godina } \\ \text { Year }\end{array} & \begin{array}{l}\text { Ukupan broj hospitalizovanih } \\ \text { TOTAL hospitalized }\end{array} & \begin{array}{l}\text { Hospitalizovani zbog ketoacidoze } \\ \text { i hiperosmolarne kome } \\ \text { Hospitalized for DKA and NHOK }\end{array} & \begin{array}{l}\text { Procentualni odnos } \\ \text { Percentage ratio }\end{array} \\ \begin{array}{l}\text { 2007. god } \\ \text { 2007. year }\end{array} & 462 & 17 & 3.68 \% \\ \begin{array}{l}\text { 2008. god } \\ \text { 2008. year }\end{array} & 528 & 14 & 2.65 \% \\ \begin{array}{l}\text { 2009. god } \\ \text { 2009. year }\end{array} & 632 & 15 & 2.37 \% \\ \begin{array}{l}\text { 2010. god } \\ \text { 2010. year }\end{array} & 781 & 12 & 1.53 \% \\ \text { Ukupno } & 2403 & 56 & \\ \text { Total } & & & \\ \end{array}$

u broju hospitalizacija zbog akutnih komplikacija dijabetesa kroz godine posmatranja.

U pacijenata sa DKA prosečne vrednosti na prijemu su bile: glikemija $32 \mathrm{mmol} / \mathrm{l}, \mathrm{HbAlc} 11,6 \%$, pH 6.89, HCO3 $7,40 \mathrm{mEq} / \mathrm{l}$. Kod pacijenata sa NHOK prosečna glikemija $60,35 \mathrm{mmol} / \mathrm{l}$, HbAlc 11,2\%, pH 7,43, a HCO3 19,8 mEq/l (Tabela 4).

Poredeći visinu glikemije, HbAlc, pH i bikarbonata na prijemu među pacijentima sa DKA i NHOK dobijena je visoko statistički značajna razlika u visini glikemije $(\mathrm{t}(54)=6,03, \mathrm{p}<0,01)$ i vrednosti bikarbonata $(\mathrm{t}(54)=3,72$, $\mathrm{p}=0,01) . \mathrm{Za}$ vrednosti HbA1c $(\mathrm{t}(54)=0,25, \mathrm{p}>0,05)$ i $\mathrm{pH}$ krvi $(\mathrm{t}(54)=0,81, \mathrm{p}>0,05)$ ne postoji statistički značajna razlika između ove dve grupe pacijenata.

Prosečna vrednost HbAlc bila je 11,6 \%. Posmatrali smo u kojoj meri predhodna glikoregulacija utiče na ozbiljnost metaboličkog poremećaja u ketoacidozi. Jednofaktorskom parametarskom analizom varijanse (ANOVA) upoređene su vrednosti HbAlc u bolesnika sa blagim, umerenim i teškim oblikom ketoacidoze, podeljenih u date grupe na osnovu izmerenog nivoa bikarbonata (Tabela 5) i pH krvi na prijemu (Tabela 6). Ne postoji statistički značajna razlika u nivou HbAlc između ove tri grupe pacijenata.

Najčešći precipitirajući faktori bili su: infekcija i neadekvatna terapija. Znatno ređi uzroci nastanka DKA i NHOK bili su infarkt miokarda, cerebrovaskularni insult, akutni pankreatitis i akutno alkoholisano stanje (Grafikon1).

Kako je neadekvatna terapija važan precipitirajući faktor posmatrali smo terapiju na prijemu. Svi pacijenti sa NHOK i 16 osoba sa DKA bili su prethodno lečeni oralnim antihiperglikemijskim lekovima, dok je 29 njih sa DKA bilo prethodno na insulinskoj terapiji. Devet pacijenata (4 osoba- DM tip 1 i 5 osoba- DM tip2) nije imalo predhodnu terapiju. Od njih devet u 5 slučajeva u pitanju je bila prva manifestacija DM (de novo), a 4 bolesnika samoinicijativno su prekinula terapiju na duži period (Tabela 7). 


\begin{tabular}{|c|c|c|c|}
\hline \multicolumn{4}{|c|}{$\begin{array}{c}\text { Tabela 4. Vrednosti na prijemu; } \\
\text { Table } 4 \text {. Values on admission }\end{array}$} \\
\hline Prosečne vrednosti na prijemu & DKA & NHOK & $\mathrm{P}$ \\
\hline Values on admission & 54pacijenta & 2 pacijenta & $\mathrm{P}$ \\
\hline & 54 patients & 2 patients & \\
\hline Glikemija mmol/l & $32 \pm 8.85$ & $60.35 \pm 15.14$ & $<0.01$ \\
\hline Glycemia mmol71 & & & \\
\hline $\begin{array}{l}\mathrm{HbA} 1 \mathrm{c} \% \\
\mathrm{HbA1c} \%\end{array}$ & $11.6 \pm 2.52$ & $11.2 \% \pm 1.7$ & $>0.05$ \\
\hline $\begin{array}{l}\mathrm{pH} \\
\mathrm{PH}\end{array}$ & $6.89 \pm 0.17$ & $7.43 \pm 0.1$ & $>0.05$ \\
\hline $\begin{array}{l}\mathrm{HCO} 3 \mathrm{mEq} / 1 \\
\mathrm{HCO} 3 \mathrm{mEq} / 1\end{array}$ & $7.40 \pm 5.03$ & $19.8 \pm 5.23$ & $=0.01$ \\
\hline $\begin{array}{l}\text { Anjonska praznina } \\
\text { Anion gap }\end{array}$ & 18 & 15 & I \\
\hline Osmolarnost mosm/1 & & & \\
\hline Osmolality mosm/L & $348 \pm 3.47$ & $375 \pm 2.56$ & / \\
\hline
\end{tabular}

\begin{tabular}{|c|c|c|}
\hline $\begin{array}{l}\text { Table } 5 . \mathrm{HbA1C} \text { Value dis } \\
\text { forms DKA based on the }\end{array}$ & $\begin{array}{l}\text { lay in patients with } \\
\text { alue of bcarbonates }\end{array}$ & rious \\
\hline Nivo bikarbonata (mEq/l) & Vrednosti HbA1c & $\mathrm{N}$ \\
\hline Levels of bicarbonate & HbAlc values & $\mathrm{N}$ \\
\hline$<10.00$ & $11.57 \pm 2.49$ & 39 \\
\hline $10.01-15.00$ & $12.16 \pm 2.23$ & 10 \\
\hline$>15.01$ & $11.14 \pm 3.60$ & 5 \\
\hline
\end{tabular}

$\mathrm{F}=0.315, \mathrm{p}>0.05(\mathrm{~F} 2,51 ; 0.05=3.23$ i $\mathrm{F} 2,51 ; 0.01=5.18)$
Tabela 6. Prikaz vrednosti HbAlc u pacijenata sa različitim oblicima DKA na osnovu nalaza $\mathrm{pH}$ krvi

Table 6. HbA1C Value display in patients with various forms DKA based on the value of blood $\mathrm{pH}$

$\begin{array}{lll}\text { pH krvi } & \text { Vrednosti HbAlc } & \text { N } \\ <7.00 & 11.64 \pm 3.36 & 14 \\ 7.01-7.24 & 11.90 \pm 1.93 & 28 \\ >7.25 & 11.03 \pm 2.74 & 12\end{array}$

$\mathrm{F}=0.503, \mathrm{p}>0.05(\mathrm{~F} 2,51 ; 0.05=3.23$ i $\mathrm{F} 2,51 ; 0.01=5.18)$

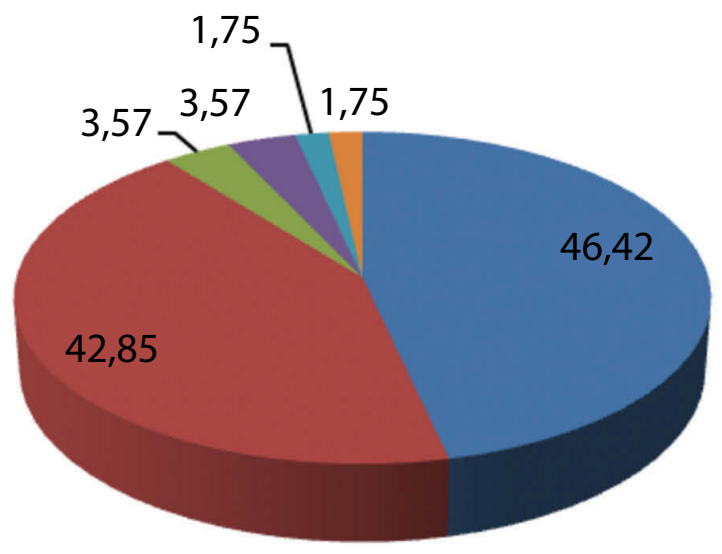

- infekcija (infection)

neadekvatna terapija (inadequate therapy)

- infarkt miokarda (myocardial infarction) ncerebrovaskularni insult (cerebrovascular insult) akutni pankreatitis (acute pancreatitis)

- akutno alkoholisano stanje (acute alcohol)

Grafikon 1. Precipitirajući faktori za razvoj DKA i NHOK

Graph 1. Precipitating factors for the development of DKA and NHOK 


\section{Tabela 7. Prikaz predhodne terapije}

Table 7. Previous therapy

$\begin{array}{llll}\text { ORA } & \begin{array}{l}\text { Oralni antihiperglikemici } \\ \text { Oral antidiabetics }\end{array} & \begin{array}{l}\text { Insulinska terapija } \\ \text { Insulin }\end{array} & \begin{array}{l}\text { Bez terapije } \\ \text { No therapy }\end{array} \\ \begin{array}{l}\text { Osobe sa DKA } \\ \text { Patients diagnosed with DKA }\end{array} & 16(29.6 \%) & 29(53.7 \%) & 9(16.7 \%) \\ \begin{array}{l}\text { Osobe sa NHOK } \\ \text { Patients diagnosed with NHOK }\end{array} & 2(100 \%) & / & /\end{array}$

Tabela 8. Glikemija po grupama u zavisnosti od predhodne terapije

Table 8. Glycemia in groups depending of previous treatment

$\begin{array}{lll}\begin{array}{l}\text { Predhodna terapija } \\ \text { Previous treatment }\end{array} & \begin{array}{l}\text { Glikemija na prijemu } \\ \text { Glycemia on admission }\end{array} & \text { N } \\ \begin{array}{l}\text { Grupa 1 (oralna terapija) } \\ \text { Group 1 (oral therapy) }\end{array} & 29.77 \pm 4.80 & 29 \\ \begin{array}{l}\text { Grupa 2 (insulinska terapija) } \\ \text { Group 2 (insulin therapy) }\end{array} & 31.99 \pm 7.26 & 9 \\ \begin{array}{l}\text { Grupa 3 (bez predhodne terapije) } \\ \text { Group 3 (without previous therapy) }\end{array} & 27.68 \pm 5.75 & \end{array}$

Poređene su srednje vrednosti biohemijskih parametara (glikemije, bikarbinata i $\mathrm{pH}$ ) po grupama koje su formirane na osnovu predhodne terapije. Ne postoji statistički značajna razlika u visini glikemije na prijemu između grupe 1 i grupe $2(t(43)=0,83, p>0,05)$ niti između grupe 1 i grupe $3(t(23)=0,49, p>0,05)$. Poredeći grupu pacijenata lečenih insulinom i one bez predhodne terapije $t$ testom nije detektovana razlika $u$ nivou glikemije na prijemu $(\mathrm{t}(36)=1,34, \mathrm{p}>0,05)$ (Tabela 8).

Između grupe 1 i grupe $2(t(43)=2,16, p<0,05)$, kao i izmedu grupe 1 i $3(\mathrm{t}(23)=2,02, \mathrm{p}<0,05)$ postoji statistički značajna razlika u nivou bikarbonata na prijemu. Između i grupe 2 i 3 ne postoji značajna razlika u nivou bikarbonata $(t(36)=1,62, p>0,05)$ (Tabela 9). Predhodna terapija nije bitno uticala na nivo $\mathrm{pH}$ vrednosti krvi (Tabela 10). Izmedju grupa 1 i 2 ne postoji statistički značajna razli- ka u vrednosti pH krvi $(\mathrm{t}(43)=1,61, \mathrm{p}>0,05)$. Takođe, ne postoji razlika između grupe 2 i $3(t(36)=0,28, p>0,05)$ i grupe 1 i $3(t(23)=0,87, p>0,05)$.

Lečenje hospitalizovanih pacijenata podrazumevalo je rehidrataciju, frakcionirano davanje bolusnog HM insulina, nadoknadu kalijuma i odgovarajuće lečenje precipitirajućeg faktora. Rehidratacija je ostvarena prvog dana sa prosečno 5,6 litara, drugog dana 4,08, a trećeg 3 litara infuzionih rastvora. Ukupna dnevna doza bolusnog HM insulina prvog dana bila je 81,04i.j, drugog 59,64 i.j, a trećeg 58,06 i.j. Maksimalna dnevna nadoknada kalijuma u obliku $7.4 \%$ rastvora KCL bila je $110 \mathrm{mmol} / \mathrm{l}$, a minimalna $20 \mathrm{mmol} / \mathrm{l}$. U tri bolesnika nije bilo potrebe za nadoknadom kalijuma (Tabela 11). Posmatrano je da li i u kojoj meri predhodna terapija kojom je pacijentima regulisan dijabetes melitus određuje intenzitet lečenja u

Tabela 9. Bikarbonati po grupama u zavisnosti od predhodne terapije

Table 9. Bicarbonates in groups depending of previous treatment

$\begin{array}{llc}\text { Predhodna terapija } & \text { Bikarbonati na prijemu } \\ \text { Previous treatment } & \text { Bicarbonates on admission } & \mathrm{N} \\ \begin{array}{l}\text { Grupa 1 (oralna terapija) } \\ \text { Group 1 (oral therapy) }\end{array} & 9.17 \pm 2.42 & 16 \\ \begin{array}{l}\text { Grupa 2 (insulinska terapija) } \\ \text { Group 2 (insulin therapy) }\end{array} & 6.00 \pm 1.01 & 29 \\ \begin{array}{l}\text { Grupa 3 (bez predhodne terapije) } \\ \text { Group 3 (without previous therapy) }\end{array} & 5.95 \pm 1.53 & 9\end{array}$


Tabela 10. Vrednost pH krvi po grupama u zavisnosti od predhodne terapije

Table 10. Value $\mathrm{pH}$ groups depending of previous treatment

\begin{tabular}{lll}
$\begin{array}{l}\text { Predhodna terapija } \\
\text { Previous treatment }\end{array}$ & $\begin{array}{l}\text { pH krvi na prijemu } \\
\text { Blood pH on admission }\end{array}$ & $\mathrm{N}$ \\
$\begin{array}{l}\text { Grupa 1 (oralna terapija) } \\
\text { Group 1 (oral therapy) }\end{array}$ & $7.15 \pm 0.15$ & 16 \\
$\begin{array}{l}\text { Grupa 2 (insulinska terapija) } \\
\text { Group 2 (insulin therapy) }\end{array}$ & 29 \\
$\begin{array}{l}\text { Grupa 3 (bez predhodne terapije) } \\
\text { Group 3 (without previous therapy) }\end{array}$ & $7.07 \pm 0.16$ & 9 \\
\hline
\end{tabular}

Tabela 11. Prosečna terapija u prva tri dana intenzivnog lečenja

Table 11.Average treatment in the first three days of treatment

\begin{tabular}{lccc} 
& $\begin{array}{l}\text { Nadoknada tečnosti(L) } \\
\text { Volume replacement }\end{array}$ & $\begin{array}{l}\text { Insulinska } \\
\text { Terapija (i.j.) } \\
\text { Insulin therapy (i.j.) }\end{array}$ & $\begin{array}{l}\text { Nadoknada kalijuma mmol/L(7.4\%KCl) } \\
\text { Compensation potassium } \\
\text { mmol/L(7.4\%KCl }\end{array}$ \\
$\begin{array}{l}\text { Prvi dan } \\
\text { First day }\end{array}$ & $5.6 \pm 1.65$ & $81.4 \pm 27.97$ & $61 \pm 18.70$ \\
$\begin{array}{l}\text { Drugi dan } \\
\text { Second day }\end{array}$ & $4.08 \pm 0.87$ & $59.64 \pm 17.60$ & $36 \pm 10.69$ \\
$\begin{array}{l}\text { Treći dan } \\
\text { Third day }\end{array}$ & $3.1 \pm 1.01$ & $58.06 \pm 19.70$ & $45 \pm 7.90$ \\
\hline
\end{tabular}

prva tri dana u stanju dijabetesne ketoacidoze. Poredili smo prosečan broj jedinica insulina i prosečnu količinu date tečnosti u prva tri dana lečenja kod grupe pacijenta lečenih oralnom, insulinskom terapijom i u grupi bez terapije jednofaktorskom parametarskom analizom varijanse (ANOVA) (Tabela 12).

Empirijska vrednost Fisherovog količnika za jedinice insulina je $\mathrm{F}=1,07, \mathrm{p}>0,05 \quad(\mathrm{~F} 2,51 ; 0,05=3,23$ i F2,51;0,01=5,18). Ne postoji statistički značajna razlika u broju jedinica insulina u prva tri dana lečenja između ove tri grupe pacijenata.
Empirijska vrednost Fisherovog količnika za količinu tečnosti je $\mathrm{F}=0,82$, p $>0,05$ (F2,51;0,05=3,23 i F2,51;0,01=5,18).

Najčešća komplikacija bila je hipokalijemija, prisutna u 29 (51,78\%) lečenih. Najniža vrednost kalijuma bila je 2,7mmol/l. Ostale komplikacije bile su: akutna bubrežna insuficijencija (3 osobe), akutni respiratorni distres sindrom (2 osobe), edem pluća (2 osobe) i gastrointestinalno krvavljenje (1 osoba) (Grafikon 2).

U toku lečenja svi pacijenti su pregledani od strane oftalmologa, neurologa, nefrologa u cilju ispitivanja i praćenja prisustnih hroničnih komplikacija. Hronične komplika-

Tabela 12. Uticaj predhodne terapije na lečenje ketoacidoze

Table 12. The impact of previous therapy for treatment of ketoacidosis

$\begin{array}{llll}\begin{array}{l}\text { Predhodna terapija } \\ \text { Previous therapy }\end{array} & \text { prosečan br. jed insulina } & \text { Prosečn kol. Tečnosti } & \mathrm{N} \\ \begin{array}{l}\text { Grupa 1 (oralna terapija) } \\ \text { Group 1 (oral therapy) }\end{array} & 84.06 \pm 31.13 & 5.36 \pm 1.41 & 16 \\ \begin{array}{l}\text { Grupa 2 (insulinska terapija) } \\ \text { Group 2 (insulin therapy) }\end{array} & 80.31 \pm 27.82 & 5.79 \pm 1.81 & 29 \\ \begin{array}{l}\text { Grupa 3 (bez predhodne terapije) } \\ \text { Group 3 (without previous therapy) }\end{array} & 92.88 \pm 22.78 & 6.00 \pm 1.65 & 9 \\ & & \end{array}$




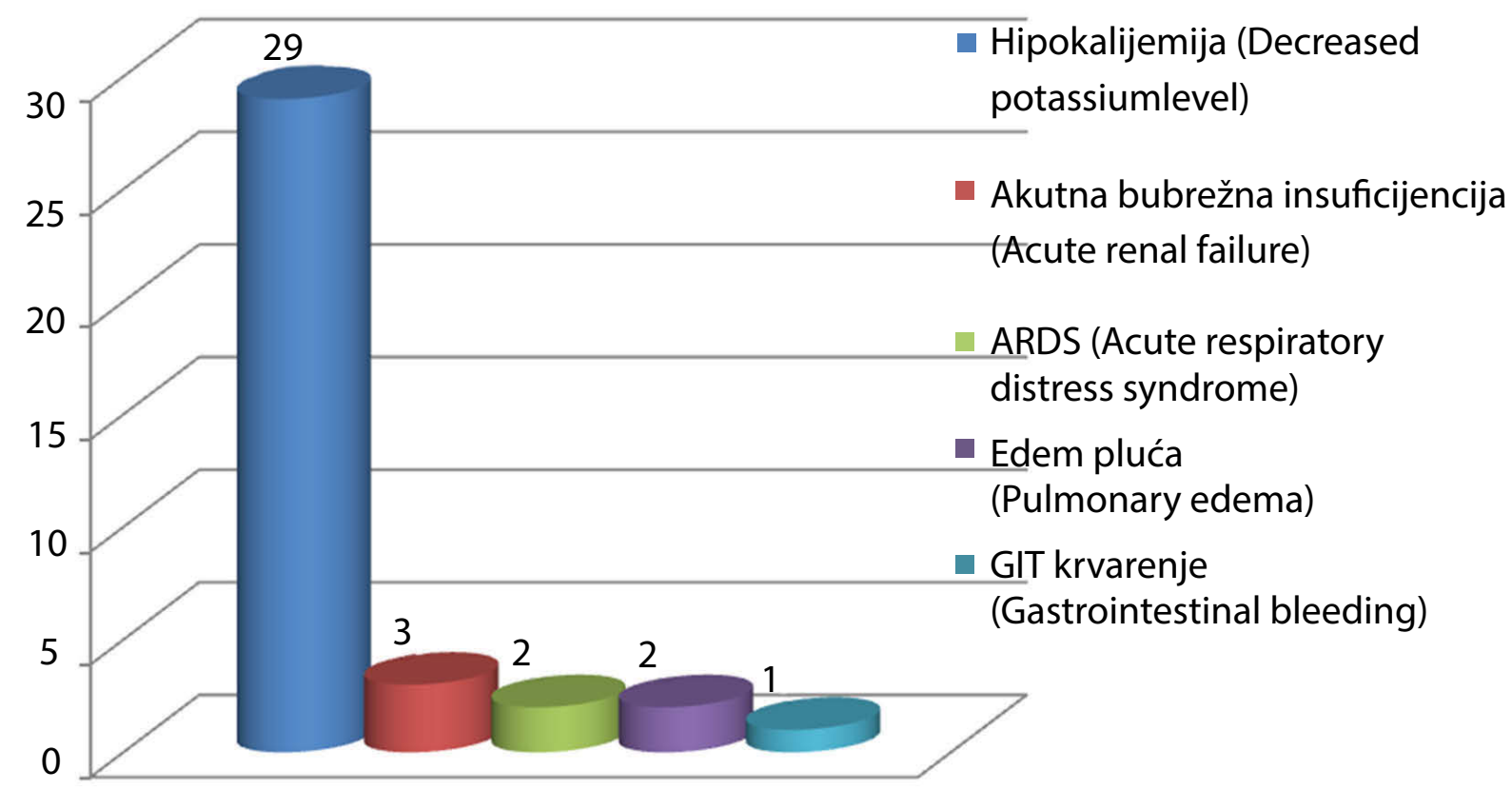

Grafik 2. Komplikacije lečenja

Graph 2. Complications of treatment

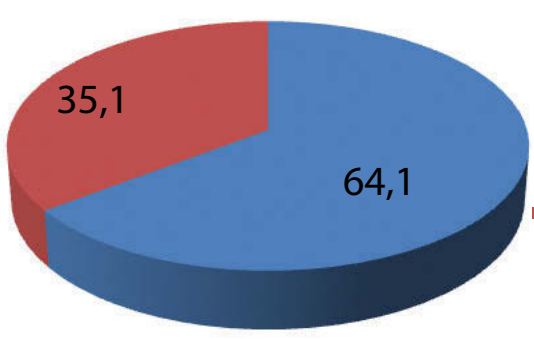

- sa hroničnim komplikacijama (with chronic complications)

bez hroničnih komplikacija (without chronic complications)

Grafik 3. Prisustvo hroničnih komplikacija

Graph 3. Presence of chronic complications cije DM su bile prisutne kod više od polovine pacijenata, u $36(64,90 \%)$ osoba, dok $20(35,10 \%)$ pacijenata nije imalo hronične komplikacije (Grafikon 3).

Polineuropatija je bila prisutna kod 20 osoba, retinopatija u 9 osoba, neuropatsko stopalo kod 3 pacijenta, koronarna bolest u 10 osoba, CVI u 4 osobe, dijabetesna nefropatija kod 3 pacijenta (Grafikon 4).

Po završetku lečenja, ukupno je 26 (46,42\%) osoba otpušteno na bazal-bolusnoj terapiji humanim insulinom, $18(32,14 \%)$ na bazal-bolusnoj terapiji analozima,

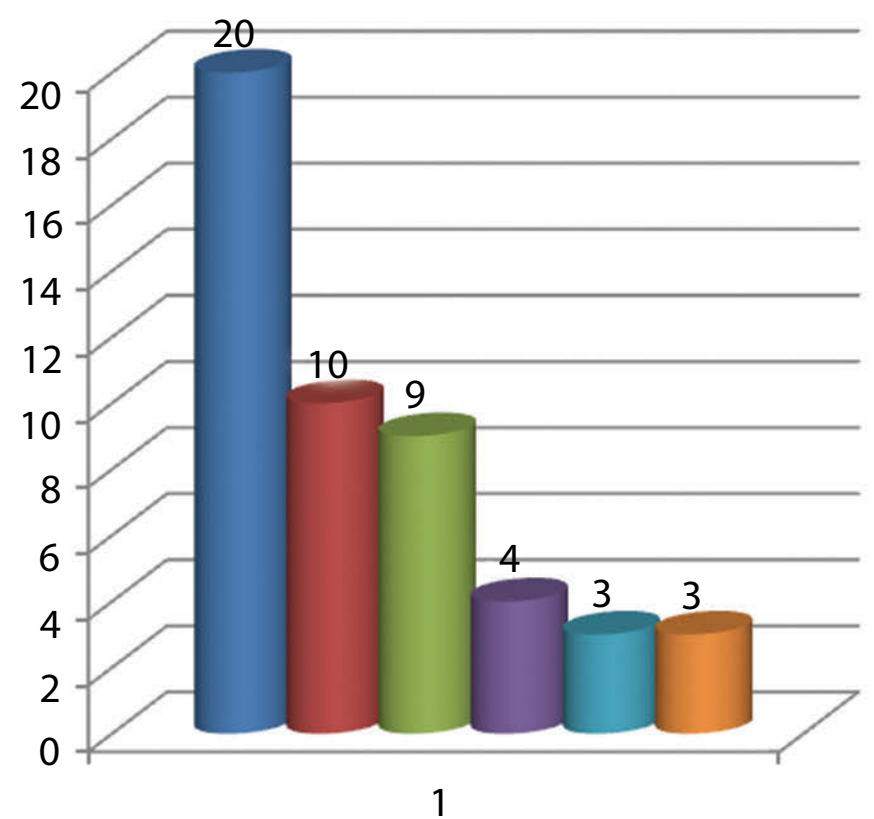

Grafik 4. Zastupljenost pojedinih hroničnih komplikacija

Graph 4. Prevalence of chronic complications
- polineuropatija (polyneuropathy)

- koronarna bolest (coronary disease)

retinopatija (retinopathy)

- CVI (cerebrovascular insult)

- dijabetesna neuropatija (diabetic neuropathy) neuropatsko stopalo (neuropathic foot) 


\section{Tabela 13. Prikaz terapije na otpustu}

Table 13. Therapy at discharge

$\begin{array}{lll}\begin{array}{l}\text { Terapija na otpustu } \\ \text { Therapy at discharge }\end{array} & \text { DKA } & \text { NHOK } \\ \begin{array}{l}\text { Bazal bolusna terapija HM insulinima } \\ \text { Basal bolus HM insulin therapy }\end{array} & 25 & 1 \\ \begin{array}{l}\text { Terapija humanim analozima } \\ \text { Basal bolus analogues }\end{array} & 18 & / \\ \begin{array}{l}\text { Premiks insulina i metformina } \\ \text { Premix insulin metformin }\end{array} & 11 & / \\ \begin{array}{l}\text { Oralna terapija } \\ \text { Oral therapy }\end{array} & 1 & 1\end{array}$

$11(19,64 \%)$ na kombinovanoj terapiji premiks insulina i metformina, dok je dvoje $(3,57 \%)$ otpušteno na oralnim antihiperglikemijskim lekovima (Tabela 13).

Ishod lečenja je bio upešan u 50 osoba (89,3\%), dok je smrtni ishod nastupio u njih 6 (10.7\%). Prosečna starost osoba koje su lečenje završile letalnim ishodom bila je $75 \pm 6,2$ godina. U pitanju su bili pacijenti sa brojnim komorbiditetima i razvijenim makrovaskularnim komplikacijama dijabetes melitusa. Svi pacijenti su imali DKA, dok je u oba pacijenta sa NHOK uspešno saniran metabolički dizbalans i otpušteni su sa korigovanom terapijom. Četiri osobe sa DKA su prebačene na druga odeljenja nakon saniranja akutnog metaboličkog poremećaja.

\section{Diskusija}

Naše ispitivanje je pokazalo da akutne komplikacije dijabetes melitusa nisu česta pojava u hospitalizivanih pacijenata. Javljaju se pretežno kod pacijenata sa komorbiditetima i predhodno lošom glikoregulacijom.

Glavni precipitirajući faktor koji je pacijente dovodio u stanje DKA i NHOK je infekcija. Respiratorne infekcije, akutizacija hroničnog bronhitisa i pneumonija, kao i urinarne infekcije su i u drugim radovima zabeležene kao vodeći precipitirajući faktor (16). Infekcija kod obolelih od dijabetesa je ozbiljna pretnja za potencijalno veoma opasne kompilkacije. Potrebno je lociranje infektivnog žarišta i primena blagovremene terapije. Drugi razlog je neadekvatna antidijabetesna terapija. Tu spadaju neblagovremena i neadekvatna primena insulinske terapije, nedovoljna komlijansa i nepridržavanje predloženim merama higijensko-dijetetskog režima. Neželjeni kardiovaskularni događaji, akutni infarkt miokarda i cerebrovaskularni insult su treći precipitirajući faktor. Dobijeni podaci se slažu sa autorima drugih radova (17).

Prosečna starost pacijenata u našem radu bila je 51 godina. Najmlađi pacijent koji je hospitalizovan zbog akuntih komplikacija imao je 18 godina. Od svih hospitalizovanih zbok stanja DKA, blizu trećine bolesnika bilo je mlađe od 40 godina. To se slaže sa literaturnim podacima gde se dijabetesna ketoacidoza javlja kod mlađih, veoma često kao prva manifestacija dijabetesa. Prema podacima iz literature DKA se češće javlja kod DM tip 1, što nije slučaj sa prikazanom grupom u kojoj su brojniji bili pacijenti sa DM tip 2 (18).

Za razliku od dijabetesne ketoacidoze NHOK se prema podacima iz literature tipično javlja kod starijih ljudi na oralnim antihiperglikemijskim sredstvima. Prosečna starost pacijenta hospitalizovanih zbog NHOK je 79,5 godina. Razlog za pojevu hiperosmolarne neketonske kome kod starijih je loša kontrola dijabetesa, nedovoljno uzimanje tečnosti, upotreba diuretika i prisutna bubrežna slabost (19). Kod oba pacijenta sa NHOK u pitanju je bio DM tip 2 predhodno lečen oralnim antidijabeticima.

Prikazana je distribucija obolelih od DKA i NHOK u posmatranom četvorogodišnjem periodu. Pad u broji hospitalizovanih zbog akutnih komplikacija dijabetesa sa smanjenim procentualnim češćem u odnosu na ukupan broj hospitalizovanih se može objasniti poboljšanjem zdravstveno vaspitnog rada. Edukacijom lekara opšte medicine moguće je doprineti boljoj kontroli dijabetes melitusa i ranijem i blagovremenom prevođenju na insulin.

Naše ispitivanje nije pokazalo da postoji korelacija izeđu visine HbAlc i stepena metaboličkog poremećaja u akutnim komplikacijama dijabetesa, što možda ne bi bilo potvrđeno drugim ispitivanjem sa većim uzorkom. Takođe, prvobitna terapija ne određuje stepen metaboličkog poremećaja. Međutim, pacijenti lečeni oralnim antihiperglikemicima su imali niži stepen acidoze u odnosu na one lečene insulinom i one bez terapije. Ovo je moguće objasniti preostalom funkcijom $\beta$ ćelija pankreasa u DM tip 2. U ovom radu nakon stabilizacije akutnog stanja nije određivana sekretorna funkcija $\beta$ ćelija niti rezerva pankreasa. Prema našem saznanju ne postoje radovi koji su uporedili pojavu akutnih komplikacija dijabetesa sa sekretornom funkcijom $\beta$ ćelija pankreasa. Predhodno lečenje nije pokazalo značajan uticaj na lečenje u prva tri dana intenzivnog tretmana.

Svi pacijenti su lečeni klasičnom terapijom za akutna stanja ove vrste. Cilj lečenja bio je da se postigne brza rehidratacija, normalizacija acido-baznog statusa, adekvatna regulacija glikemije, nadoknada K+. Pacijenti su na intenzivnom lečenju provodili u proseku 3 dana. Korigovana im je terapija i otpušteni su u stabilnom stanju. I pored intenzivnog tretmana razvijale su se komplikacije lečenja.

Najčešća komplikacija kod lečenih od DKA bila je hipokalijemija. Javljala se zbog loše nadoknade kalijuma u prvim i urgentnim terapijskim postupcima u ketoacidozi. Odluku o nadoknadi kalijuma treba uskladiti sa preporukama da se nadoknada $\mathrm{K}$ započinje kada je se- 
rumski $\mathrm{K}<5,5 \mathrm{mmol} / \mathrm{l}$. U $500 \mathrm{ml}$ rastvora stavlja se10 $\mathrm{ml}$ $7,4 \% \mathrm{KCl}$. Akutna bubrežna insuficijencija kao druga po učestalosti komplikacija ketoacidoze, javljala se kod visoko febrilnih pacijenata, sa prisutnim teškim urinarnim infekcijama. Akutni respiratorni distres sindrom razvio se na terenu egzacerbacije hroničnog bronhitisa sa lošom respiratornom rezervom. Gastroinestinalno krvarenje nastalo je kod jednog pacijenta na terenu predhodne ulkusne bolesti. Učestalost pojedinih komplikacija u srodnim ispitivanjim je slična (20).

Mortalitet u našem istraživanju (10,7\%) je bio viši u odnosu na podatke iz literature (2\%), a vezan je za precipitirajući kardiovaskularni dogadjaj i starost pacijenata sa brojnim komorbiditetima (21). Prosečna starost pacijenata kod kojih je nastupio letalni ishod bila je 75 godina. Neophodno je napomenuti da su pacijenti koji su egzitirali uspešno vođeni i lečeni i toku trajanja DKA (u toku intenzivnog lečenja). U pitanju su stari pacijenti sa brojnim komorbiditetima (dugotrajnom hipertenzijom, ishemijskom bolešću srca, kardiomiopatijom, stanjem posle cerebrovaskularnog insulta) koji su nakon stabilizacije akutnog poremećaja najčešće dobijali CVI ili infarkt miokarda, što je i potvrđeno obdukcionim nalazima.

Kada je u pitanju razvoj komplikacija i ishod lečenja pacijenata sa NHOK, ograničenje je to što su u navedenom periodu hospitalizovana samo dva pacijenta sa ovim stanjem. Oba pacijenta su otpuštena u stabilnom stanju uz korekciju terapije sto implicira da je uspešnost lečenja u ovom slučaju bila $100 \%$. U literaturni se nalazi podatak da je mortalitet $u$ lečenih usled stanja NHOK od 15-50\%. U drugim radovima se pominju tromboebolija i rabdomioliza kao česte komplikacije ovog stanja što se nije javljalo u naša dva pacijenta (22).

Hronične komplikacije dijabetes melitusa bile su prisutne kod više od polovine naših pacijenata sa DKA i NHOK. Prosečne vrednosti HbAlc su u obe grupe bile preko $11 \%$. Prema Nathan et al. preračunavajući vrednost HbAlc u nivo glikemije dobija se podatak da su pacijenti $\mathrm{u}$ predhodnom tromesečnom periodu imali prosečan nivo glikemije $12-17,5 \mathrm{mmol} / \mathrm{l}$ (23), što jasno pokazuje dugoročno lošu glikoregulaciju. Loša komlijansa i neadekvatna terapija vode do nezadovoljavajuće glikoregulacije koja predhodi akutnim i hroničnim komplikacijama dijabetesa.

Za hronične komplikacije dijabetesa nema efikasne terapije. Lečenje se svodi na zaustavljanje progresije a ostalo je simptomatska terapija. Jako je važno rano prepoznavanje bolesti i dobra metabolička kontrola. Hronične komplikacije dijabetesa su takođe i vodeći uzrok umiranja. Prema Balkau B et al. mortalitet u obolelih od dijabetesa je dva puta veći u odnosu na nedijabetičare (24). Takođe, utvrđeno je da mortalitet usled kardiovaskularnih bolesti u opštoj populaciji opada a mortalitet od šećerne bolesti raste (25). U prikazanim podacima nije postojala statistički značajna razlika u visini glikoziliranog hemoglobina kod pacijenta sa i bez hroničnih komplikacija. Prisustvo hroničnih komplikacija se nije razlikovalo u pacijenata lečenih insulinom od onih lečenih oralnim antihiperglikemicima. Statistički ne postoji značajna razlika između prisustva hroničnih komplikacija u pacijenata lečenih insulinskom terapijom u odnosu na pacijente lečene oralnim antihiperglikemicima i onih koji su predhodno bili bez terapije. Ovi podaci imaju ograničenje jer su svi pacijenti predhodno imali visoke vrednosi HbAlc i ne postoji referentna kontrolna grupa.

\section{ZAKLJUČAK}

I pored edukacije i potpune dostupnosti lekova za šećernu bolest, dijabetesna ketoacidoza i hiperosmolarna koma se javljaju, pretežno kod starijih osoba sa brojnim komorbiditetima.

Izuzetno je važan oprez kod obolelih od dijabetes melitusa u stanjima infekcije, koja nesumljivo predstavlja najznačajniji precipitirajući faktor za akutne komplikacije osnovne bolesti. Naročito je važan oprez kod starijih pacijenata koji imaju brojne komorbiditete i kod kojih se akutne komplikacije često završavaju letalnim ishodom. Neophodno je obratiti posebnu pažnju na njih u stanjima infekcije, stresogenih situacija i dehidratacije.

Redovnim praćenjem pacijenata sa dijabetesom, kontrolom glikemije i HbAlc mogu se sprečiti akutne komplikacije ove bolesti. Unapređenje edukacije pacijenata intenzivnim zdravstveno-prosvetnim radom neophodan je korak ka poboljšanju stava pacijenta prema bolesti i novom načinu života koji ona zahteva.

\section{LITERATURA}

1. Dhatariya K. Editorial. Diabetic Ketoacidosis. Brit Med J 2007;334:12841285.

2. Kitabchi AE, Umpierrez GE, Miles JM, Fisher JN. Hyperglycemic crises in adult patients with diabetes. Diabetes Care.2009;32(7):1335-1343.

3. Delaney MF, Zisman A, Kettyle WM. Diabetic ketoacidosis and hyperglycemic hyperosmolar nonketotic syndrome. Endocrinol Metab Clin North Am. 2000; 29(4):683-705

4. Umpierrez GE, Smiley D, Kitabachi AE. Narrative review: ketosis-pronetype 2 diabetes mellitus. Ann Intern Med 2006;144:350-357.

5. Gouni-Berthold I, Krone W. Diabetic ketoacidosis and hyperosmolar hyperglycemic state. Med Klin (Munich). 2006;101 Suppl 1:100-5.

6. Kisiel M, Marsons L. Recognizing and responding to hyperglycaemic emergencies. Br J Nurs. 2009;18(18):1094-8.

7. De Beer K, Michael S, Thacker $\mathrm{M}$ et al. Diabetic ketoacidosis and hyperglycaemic hyperosmolar syndrome - clinical guidelines. Nurs Crit Care. 2008;13(1):5-11

8. Kitabchi AE, Umpierrez GE, Fisher JN, Murphy MB, Stentz FB. Thirty years of personal experience in hyperglycemic crises: diabetic ketoacidosis and hyperglycemic hyperosmolar state. J Clin Endocrinol Metab 2008;93:1541-52.

9. Balogh Z, Paragh G. Diabetic metabolic emergencies. Orv Hetil. 2005; 6;146(10):443-50. 
10. Pant N, Kadaria D, Nasser W, Murillo LC, Freire AX. Diabetic ketoacidosis presenting with acute pancreatitis and visceral vein thrombosis. Tenn Med. 2011;104(5):47-50.

11. Joint British Diabetes Societies. The management of diabetic ketoacidosis in adults. 2003;9-15.

12. Cryer PE, et al. Evaluation and management of adult hypoglycaemic disorders: an Endocrine Society Clinical Practice Guideline. J Clin Endocrinol Metabol 2009:94:709-728.

13. Keenan CR, Murin S, White RH. High risk for venous tromboembolism in diabetics with hyperosmolar state:comparison with other acute medical illnesses. J Thromb Haemost 2007;5:1185-90.

14. Izumi T, Shimizu E, Imakiire $\mathrm{T}$ et al. A successfully treated case of hyperosmolar hyperglycemic state complicated with rhabdomyolysis, acute kidney injury, and

15. Reingardiene D. Hyperglycemic hyperosmolar nonketotic syndrome. Medicina (Kaunas). 2003;39(7):707-12. ischemic colitis. Intern Med. 2010;49(21):2321-6

16. Weinert LS, Scheffel RS, Severo MD et al. Precipitating factors of diabetic ketoacidosis at a public hospital in a middle-income country.Diabetes Res Clin Pract. 2012;96(1):29-34

17. Burge MR, Garcia N, Qualls CR, Schade DS. Differential effects of fasting and dehydration in the pathogenesis of diabetic ketoacidosis. Metabolism. 2001;50(2):171-7.
18. Lim S. Metabolic acidosis. Acta Med Indones. 2007;39(3):145-50.

19. Milionis HJ, Liamis GL, Elisaf MS.Hyperosmolar syndrome in a patient with uncontrolled diabetes mellitus.Am J Kidney Dis. 2001;37(5):E41.

20. Radermacher L, D'Orio V. Metabolic emergencies related to diabetes mellitus: ketoacidosis and hyperosmolar state. Rev Med Liege. 2005;60(5-6):466-71.

21. Efstathiou SP, Tsiakou AG, Tsioulos DI et al. A mortality prediction model in diabetic ketoacidosis. Clin Endocrinol (Oxf). 2002;57(5):595601.

22. Cervellin G, Comelli I, Lippi G. Rhabdomyolysis: historical background, clinical, diagnostic and therapeutic features. Clin Chem Lab Med. 2010; 48(6):749-56.

23. Nathan et al. Translating the A1C Into Estimated Glucose Value. Diabetes Care 2008;31:1473- 1478 .

24. Balkau B, PyoralaM, Shipley Met al. Non-cardiovascular disease mortality and diabetes mellitus. Lancet. 1997;350:1680.

25. Sobel BE, Frye R, Detre KM et al. Burgeoning dilemmas in the management of diabetes and cardiovascular disease: rationale for the Bypass Angioplasty Revascularization Investigation 2 Diabetes (BARI 2D) Trial. Circulation. 2003;107(4):636-42. 